UDC 378.147.016:811.111

DOI https://doi.org/10.24919/2308-4863/37-2-45

Oleksandr PISKUNOV,

orcid.org/0000-0002-7176-7423

Candidate of Philology, Associate Professor,

Associate Professor at the Department of Germanic and Slavonic Linguistics

Donbas State Pedagogical University

(Sloviansk, Donetsk region, Ukraine) piskunov.oleksandr@gmail.com

Viktoriia ROMAN,

orcid.org/0000-0003-3468-1062

Candidate of Philology, Associate Professor,

Associate Professor at the Department of Germanic and Slavonic Linguistics

Donbas State Pedagogical University

(Sloviansk, Donetsk region,Ukraine) roman.victoriya2016@gmail.com

\title{
TO THE QUESTION OF ACADEMIC WRITING IN THE FORMATION OF STUDENTS' FOREIGN LANGUAGE ACADEMIC LITERACY AT HIGHER EDUCATIONAL ESTABLISHMENTS
}

\begin{abstract}
The article presents an investigation devoted to the essence of academic literacy in the process of formation of students' academic literacy at higher educational establishments. The main concern of the paper is to define the main features of teaching academic writing in a foreign language as a type of speech activity in the process of preparation of prospective foreign language teachers. Previous studies indicate that taking into consideration the fact that a collateral and a secondary treatment concerning the development of writing skills and their factual elimination from the process of teaching a foreign language and the development of writing skills mostly has remained beyond the scope of specialists in educational methods what in its turn it has proved a considerable drawback in the sphere of preparation of foreign language teachers; though this fact determines the topicality of the studying the problem of teaching writing speech at higher educational establishments. The paper provides different approaches to the question of academic writing in the context of foreign language preparation as well as methods of teaching scientific and problem-thematic communication in English, genre and linguo-didactic techniques of teaching English for scientific and academic purposes, interactive methods of teaching academic writing using computer based approach and so on. The investigated research shows that owing to academic writing the skill to produce new ideas, analyze, present the in the form structured and coherent text is developed. The obtained results show that the key to successful teaching students' academic writing is to adhere to the principle of continuity and steadiness, systematic and complex approach at all levels. According to the results of investigation discursive skills and habits of formation writing academic discourse in relation to the rules and structures of foreign letter writing should be included into the contents of teaching academic foreign language discourse. In our future research we intend to concentrate on developing methodological guidelines regarding the improvements of writing skills at foreign language classes as well as preparing written papers while students ' self-study work.
\end{abstract}

Key words: academic writing, discourse, academic literacy, speech activity, competence approach, writing speech.

Олександр ПІСКУНОВ, orcid.org/0000-0002-7176-7423 кандидат філологічних наук, доиент, доиент кафедри германської та слов'янської філологї Донбаського державного педагогічного університету (Слов’янськ, Донеиька область, Україна) piskunov.oleksandr@gmail.com

Вікторія РОМАН, orcid.org/0000-0003-3468-1062 кандидат філологічних наук, доиент, доиент кафедри германської та слов'янської філології Донбаського державного педагогічного університету (Слов'янськ, Донеиька область, Україна) roman.victoriya2016@gmail.com 


\section{ДО ПИТАННЯ АКАДЕМІЧНОГО ПИСЬМА У ФОРМУВАННІ ІНШОМОВНОЇ АКАДЕМІЧНОЇ ГРАМОТНОСТІ СТУДЕНТІВ ЗАКЛАДІВ ВИЩОЇ ОСВІТИ}

У статті представлено дослідження, присвячене значенню академічного письма у процесі формування іншомовної академічної грамотності студентів педагогічних ЗВО. Завдання роботи вбачаємо у визначенні особливостей навчання академічному письму іноземною мовою як виду мовленнєвої діяльності у проиесі підготовки майбутнього вчителя іноземної мови. Беручи до уваги факт побічного і другорядного ставлення до розвитку навичок письма і фактичного їх усунення із проиесу навчання іноземної мови, а сам розвиток навичок письма у багатьох випадках залишався поза увагою методистів, щзо було значним прорахунком у системі підготовки майбутніх фахівців з іноземних мов; саме цей момент визначає актуальність дослідження проблем навчання писемного мовлення у ЗВО. У роботі розглянуто різноманітні підходи до проблеми академічного письма в контексті іншомовної підготовки: методики навчання написання наукового проблемно-тематичного повідомлення англійською мовою, жанрової лінгводидактичної моделі викладання англійської мови для науково-академічних иілей, інтерактивного навчання академічного мовлення з використанням комп 'ютерних технологій $і$ т. д. Проведене дослідження демонструє, що саме завдяки академічному письму розвивається вміння народжувати ідеї, аналізувати, представляти інформацію у формі структурованого, зв'язаного тексту. Отримані результати показують, щчо запорукою формування академічної грамотності студентів є дотримання приничиу безперервності та наступності, системного комплексного підходу на всіх етапах освіти. Згідно з результатами дослідження у зміст навчання академічного дискурсу іноземною мовою необхідно долучати дискурсивні уміння і навички організаціі письмового академічного дискурсу відповідно до традщиій іншомовного письма. Перспективною до вирішення у подальшій діяльності вважаємо розробку методичних рекомендацій викладачам ЗВО щчодо удосконалення навичок письма на заняттях з іноземної мови та написання письмових робіт під час самостійної роботи студентів.

Ключові слова: академічне письмо, дискурс, академічна грамотність, мовленнєва діяльність, компетентнісний підхід, писемне мовлення.

Formation of the problem. The beginning of the $21^{\text {st }}$ century is marked by significant changes in the field of education in the sphere of education due to Ukraine's accession to the Bologna Education Area. One of the most important strategic objectives of modernization of the higher education system in Ukraine at the present stage is to ensure the quality of specialists' training at the level of international standards; the integration of higher education into the international education system, in particular, in the field of foreign language teaching is becoming especially important. The integration process consists in the implementation of European norms and standards into education, spreading their own cultural achievements in the European Union. These processes are becoming significant in defining educational strategies. The standards of the quality of higher education are defined as professional competence of the graduate, social and value orientation, the ability to meet personal spiritual and material needs and the needs of the society. To solve the problem of preparation of a competent specialist applying to pedagogical profile within the context of a new language strategy there is an urgent need to modernize the content, forms and methods of a professional preparation of prospective foreign language teachers what in its turn it leads to the actualization of the problem in specification of students' academic competence. The methodological basis of the research is ensured in the system-activity and competence approaches which imply different directions of the educational process and they can be organically a supplement each other. Thus this is what determines the actuality of the research.

Analysis of recent research and publications. The peculiarities of teaching writing in a foreign language as a type of a speech activity have been studied by a number of scientists (O. B. Tarnopolskyi, L. V. Kurylo, T. V. Yakhontova and so on). The question of developing skills of foreign language speech for the preparation of prospective foreign language teachers is revealed in the studies of domestic and foreign scientists such as E. V. Vasilieva, O. M. Fentsyk, L. V. Kurylo, S. Yu. Nikolaieva, O. M. Semenoh, O. F. Fast, O. S. Synekop, V. Evans, E. Hall, L. HampLyons, and others. However the peculiarities of teaching academic writing (the term given by O. B. Tarnopolskyi) remain still insufficiently studied. Thus, T. V. Yakhontova suggests a genre linguo-didactical model of teaching English for scientific and academic purposes (Yakhontova, 2002); E. V. Vasilieva in her works studies the method of teaching scientific problem-thematic information in English (Vasilieva, 2005); L. V. Kurylo considers the issue of creating a subsystem of exercises for teaching prospective teachers of English professionally oriented and scientific written speech (Kurylo, 2013); O. S. Synekop investigates the features of interactive learning of academic speech based on computer technology (Synekop, 2010); O. M. Semenoh covers the problem of academic writing in the context of English language training (Semenoh, Fast, 2015). Thus according to the opinion of Ye. I. Pasov writing speech has been considered an unimportant kind of speech activity and it 
has been almost eliminated from the process of teaching a foreign language, and the development of writing skills in many cases remained out of the methodologists' attention what was a significant drawback in the training system (Pasov, 1991).

As far we are concerned the main factors can be considered the lacks of understanding of basic approaches in research, insufficient development of theoretical and practical principles of preparation professionals on a competency basis as well as the appropriate methodological support of the teaching process, the use of outdated traditional techniques. Accordingly the urgency of the problem, its insufficient studying determined the relevance of the work carried out.

The aim of the article is to consider the peculiarities of the formation of students' academic literacy and current tendencies contributing to the improvement of students' writing speech at higher educational establishments as a key element to reach success in future professional activities.

In the structure of foreign language professional communicative competence academic literacy holds an important place being one of the main indicators of the quality of training of a modern specialist in the system of higher education. What motivates us to study this issue at the present stage? The reasons are the following: relatively low level of the development of writing communication skills even in the native language; introduction of writing foreign language competence to the list of universal and professional competencies; increasing the level of academic mobility caused by crucial changes in the system of education in the first decade of the $21^{\text {st }}$ century.

Presenting the main material. Taking into account the didactic principles of both writing and reading can be seen as a subsidiary element of speech activity as it is derived from oral speech and appeared at a much later stage of human development than speaking and listening (Tarnopolskyi, Kozhushko, 2008; 13). But taking into account the synchronic level, written types of speech activity (both reading and writing) have acquired greater informative significance compared to verbal communication. Linguodidactics considers academic literacy primarily as the ability of academic discourse defined as receptive and productive skills and abilities of oral and written academic speech, a certain way of thinking corresponding to the requirements of the given cultural environment, the ability to think critically necessary for the realization of academic activity (Tarnopolskyi, Kozhushko, 2008; 15).

Following the opinions given by O. M. Semenoh, N. V Smirnova and O. M. Fentsyk we consider that of a principal importance for the formation of academic literacy is the ability to increase self-educational competence that is preparation for self-studying cognitive activity and lifelong education, the ability to set learning goals independently and look for ways to achieve them. O. M. Semenoh states that the term 'academic writing' is regarded as methodology and the process of writing scientific texts (graduate papers, scientific articles, monographs, scientific) and practical skills (formation of skills and habits to express thoughts, ideas, structure, compress, edit, prepare a scientific text, convey it to the addressees) (Semenoh, Fast, 2015: 4-5). While formation speech academic skills great attention is paid to written academic writing since it is academic writing that develops the ability to generate ideas, the ability to analyze, express and present information in the clearly structured, coherent, logically constructed text in which the author's intention is realized in linguistic and pragmatic ways what in its turn makes writing effective means of developing critical thinking. O. B. Tarnopolskyi states that discourse is not just a text but a text within a real speech communication taken from all the wealth of extralinguistic factors determining its generation and perception (Tarnopolskyi, Kozhushko, 2008: 34). Therefore in the definition of academic written discourse as a creation of speech-thinking activity of a coherent text it should be taken into account the process itself of speech interaction which can be organized considering thematic and standard norms in combination with extralinguistic factors, opinions, goals and role functions of the communicants necessary to understand the text. As O. M. Semenoh considers that scientific language culture can be treated as the normative usage of scientific language in oral and written, dialogic and monologue forms along with the formation of a high level in linguistic and communicative culture (Semenoh, Fast, 2015: 36).

The necessity to master written discourse strategies is caused by increasing requirements to comprehend the presentation ensuring the integrity and coherence of the text. The author's concept of a written message and the recipient of this message is inseparably linked with the extralinguistic component i. e. pragmatic and sociocultural factors of speech, knowledge of the national and cultural peculiarities of the rules of the written speech interaction what in its turn can be called the sociocultural competence of the writer (Kaplich, 1996). The latter represents the skills and habits of discourse production in accordance with the compositional scheme adopted within the national cultural context. The given idea can be illustrated by the example of O. B. Tarnoposkyi. He considers that English written text becomes a discourse if we 
take into account exactly the socio-cultural features that underlie its construction, the author of the text and his worldview, attitudes, intentions, goals and desires that can inspire to read the text (Tarnopolskyi, Kozhushko, 2008: 34).

We support the definition of 'academic discourse' given by O. M. Fentsyk in her research that academic discourse is defined as a communicative interaction of members in the academic community in order to present scientific ideas, exchange educational and scientific information in oral and written forms (Fentsyk, 2020: 228).

Foreign language academic literacy should be required today from students of linguistic and nonlinguistic specialties. However, as we can highlight that mastering the skills and habits of foreign language academic writing is hampered by the lack of teaching native academic language. Thus, students, teachers of foreign languages and translators inevitably find themselves involved in research activities in their native and foreign languages, as well as in professional and communicative activities, both educational and scientific activities. This fact determines the special importance of writing for teaching foreign languages. Comprising four types of speech activities writing equally contributes to the development of each of them. Therefore excluding or restricting writing in the learning process we thereby deprive ourselves of one of the most powerful means of developing and improving the skills and habits of reading, speaking and listening. As a productive kind of speech writing is based on orientally-researched activities of the writer. The latter focuses in the perception of what is written by the future reader based on his own goals and intentions trying to force the reader to perceive the produced text exactly as it is needed and it is desirable to those who writes it. In such a full awareness and constant repeated corrections and modifications one can see the main difference between writing and other kinds of speech activities (Tarnopolskyi, Kozhushko, 2008: 15).

According to the opinion by O. M. Fentsyk, academic literacy is a complex multicomponent unity that integrates knowledge and outlook (worldview), the individual's intellectual and communicative skills; the formation of academic writing can be a purposeful, systematic process of acquiring competencies initiated during training in secondary general education institutions and which continues during professional training at higher educational establishments (Fentsyk, 2020: 228). This direction corresponds to the anthropocentric paradigm, according to which the list of research interests includes the issues distinguished by their interdisciplinary and practical character. The reveal of typological features, i.e. the determination of different and similar facts by any indicator contributing to understanding of the construction features of institutional discourse is of particular importance in the era of globalization and professional mobility (Khutyz, 2017: 180-183).

The placement towards the form is expressed both in a clear discourse structuring and in a strict sequence of all its parts. The peculiarity of English discourse is its content linear organization whereas the English paragraph is built around the main idea developed in the paragraph sentences and summarized in the final sentence; the paragraph structure reflects the structure of the whole text. The texts consisting of several paragraphs possess the introductory, main and closing parts. The presentation of the written text should be understandable, unambiguous, not allowing the use of complex, unreadable sentences (Hamp-Lyons, 2010).

In Ukrainian academic writing, deviations from the topic is not a serious code contradiction of the norms. Besides, the English language discourse is characterized by a more author's personal attitude to the problem under consideration and the reader, who should be maximally involved in the discussion of the issues raised. To establish a dialogue with the recipient of his message and keep his attention, the English-speaking author carefully builds the structure of the discourse, offers a detailed commentary, and makes references to the previous scientific works. The reasons for these differences are related to the national cognitive world picture of the carriers with different linguistic cultures. The utmost clarity in reasoning, unambiguity of verbal expression and clear assessment are required in English-speaking culture (Hall, 1976).

The fact given above explains the orientation of the English-language discourse towards the reader. The author considers himself responsible for the adequate perception of his message by the reader, the difficulties arising in the process of understanding are anticipated (Khutyz, 2017:180-183). O. B. Tarnopolskyi claims that in the aspect of development of domestic methods of teaching English-language writing, one should rely on Western communicative approaches and methods, but not mechanically transfer them to Ukrainian educational system (Tarnopolskyi, Kozhushko, 2008: 6). Many attempts to transfer Western variations of the communicative method for teaching various types of speech activity in Ukrainian educational establishments without any changes have been made, but none of them has yielded the expected result (Hamp-Lyons, Hyland, 2002).

This is quite natural, as the effectiveness of the communicative method, more than any other, depends 
on the specific conditions, specific learning goals, mentality and characteristics of both teachers and students. Therefore, there has been an obvious need to create a domestic Ukrainian version of this method, fully adapted to our conditions and learning goals, the mentality and characteristics of our students and teachers, the characteristics of our Ukrainian educational system. The need to take into account ethnic and cultural differences, linguistic and cultural interference in the writing of academic discourse is due to the specifics of the speech genres of this type of written speech. In the English language discourse, there is a clear division into a thesis, an argumentative part, and a conclusion. Arguments represent a logical unity. The conclusion completing the chain of argumentative unity corresponds to the logic of the thesis, i.e. all parts of the text must be subordinated to a common communicative task. One of the main linguistic and pragmatic sets of the English language academic discourse is the use of the principle of persuasion, which is implemented using a number of communicative tactics (informing, forecasting, evaluating, referring to known sources and the reader's background knowledge, etc.); its thoughtful and consistent use leads to the reader's reasonable conclusions. The combination of the above mentioned approaches as a methodological basis to create a subsystem of exercises to teach prospective English language teachers of professionally-oriented writing involves compliance with certain requirements for exercises at the level of all their mandatory components: tasks, task completion and control of the completed task.

A necessary condition for the formation of students' academic literacy is the compliance with the principle of continuity and sequence, a systematic integrated approach at all stages of education (Fentsyk, 2020).

Based on E. V. Vasilieva's research, we consider a set of exercises as combination of a group of exercises to teach a separate genre of written speech (Vasilieva, 2005). As an example, we can suggest the samples of an academic writing contest. Students can be offered to conduct it both in the full-time participation format and distant format on the Moodle platform to expand significantly the potential audience of participants and to attract students of other educational establishments. The competition aims to test students' ability to create a secondary academic text (for example, an abstract of a popular science or socio-political article) or initial writing (an essay on the topic, an essay in the appropriate format). Preliminary requirements for the structure and content of the written works, as well as the criteria for evaluating them are to be prepared (these requirements can be presented on the Moodle page). The competition is preceded by a systematic work on developing the necessary skills in the lecture theater and during self-study work. The Moodle platform has a wide range of tools for organizing self-study work both in distant and in full-time format. The 'tasks' tool allows you to input the answers both through the form and by attaching a file with the answer. The 'tasks' tool allows you not to use other software tools to save time. This tool also provides an opportunity to implement various configuration options as for the parameters for receiving responses, namely: response time, prohibition of sending a response after the programmed or limited time. It is even possible to require the student-participant to observe correct behavior in the aspect of copyright objects. The blind evaluation allows you not to submit the participants' names but at the same time, the Moodle. The teacher has at his disposal a significant number of tools for evaluating, possible accentuating, underlining text fragments, highlighting in color, strikethrough and presenting the final response to the written work. The platform calculates the amount of written work and after creating student response can send a message to respond to the student. The ability to create an archive file on the platform allows teachers to review and evaluate work for a longer time and without an Internet connection.

Conclusions. Thus, the content of teaching academic writing discourse in a foreign language should include discursive skills and skills to organizing written academic discourse in accordance with the traditions of foreign language written communication, including a great number of aspects as the ability to choose methods and techniques of developing vocabulary, phraseology, syntax, i.e. linguistic competence, knowledge of national and cultural features of the written discourse construction and the ability to operate with background knowledge in the process of intercultural written communication to make up the writer's sociocultural competence; the ability to navigate in the situation of written communication to choose the appropriate functional and semantic type and genre of the text - sociolinguistic competence. The writer's communicative competence is the ability to produce various types of discourse, including the texts of various genres within the academic discourse; it is a system with its core which can be called a discursive competence. The success of the formation of written academic competence is determined by the effective interaction of all its components. The competence of the construction of a professionallyoriented academic discourse to the author's idea, the situation of communication, the readers' expec- 
tations and needs ensures the success of communication in the academic communication sphere and indicates a high level of written speech competence as full-grown goal of teaching foreign languages at higher educational establishments.

Underestimating the role of writing in teaching foreign languages negatively affects the entire process of language learning. Nevertheless the very idea of using one speech form for the development of another is not new in the methodological literature. A promising area of research on tendencies in written speech development must be the development of methodological recommendations for the teachers of higher educational establishments to improve writing skills at foreign language classes and holding written works during students' self-study work.

\section{BIBLIOGRAPHY}

1. Васильєва Е. В. Навчання студентів мовних спеціальностей написання наукового проблемно-тематичного повідомлення англійською мовою : автореф. дис. ... канд. пед. наук : 13.00.02 / Київ. нац. лінгв. ун-т. 2005.24 с.

2. Загальноєвропейські рекомендації з мовної освіти: вивчення, викладання, оцінювання / наук. ред. укр. вид. С. Ю. Ніколаєва. Київ : Ленвіт, 2003. 273 с.

3. Каплич Л. В. Некоторые аспекты формирования письменной речевой компетенции в лингвистическом вузе. Интеграџия лингвистического и экстралингвистического знания. 1996. Вып. 434. С. 121-126.

4. Курило С. В. Вправи для навчання майбутніх викладачів англійської мови професійно орієнтованого наукового писемного мовлення. Іноземні мови. 2013. № 1. С. 28-33.

5. Пасов Е. И. Коммуникативные методы обучения иноязычному говорению. Москва : Просвещение, 1991. 223 с.

6. Семеног О., Фаст О. Академічне письмо: лінгвокультурологічний підхід : навчальний посібник. Суми : СумДПУ імені А. С. Макаренка, 2015. 221 с.

7. Синекоп О. С. Методика інтерактивного навчання англійського писемного мовлення майбутніх фахівців 3 інформаційної безпеки з використанням комп'ютерних технологій : дис. ... канд. пед. наук : 13.00.02. Київ. 2010. $370 \mathrm{c}$.

8. Смирнова Н. В. Академическая грамотность и письмо в вузе: от теории к практике. Высшее образование в России. 2015. № 6. С. 58-63.

9. Тарнопольський О. Б., Кожушко С. П. Методика навчання студентів письма англійською мовою. Вінниця : Нова книга, 2008. 288 с.

10. Тарнопольський О. Б. Writing Academically: A Coursebook for Teaching Academic Writing in English to Students of Linguistic Tertiary Educational Institutions: Київ : Фірма «ІНКОС», 2006. 228 c.

11. Фенцик О. М. Формування академічної грамотності здобувачів вищої освіти у процесі фахової підготовки. Педагогіка формування творчої особистості у вищій і загальноосвітній школах. 2020. Вип. 73. Ч. 2. С. $226-231$. URL: http://www.pedagogy-journal.kpu.zp.ua/archive/2020/73/part_2/45.pdf.

12. Яхонтова Т. В. Основи англомовного наукового письма: навч. посібник для студентів, аспірантів і науковців. Львів : Видавничий центр ЛНУ ім. Івана Франка, 2002. 220 с.

13. Хутыз И. П. Типологические характеристики конструирования инстиуционального дискурса в кросскультурном пространстве. Филологические науки. Вопросы теории и практики. Тамбов : Грамота, 2017. № 10. Ч. 1. C. 180-183. URL: https://cyberleninka.ru/article/n/tipologicheskie-harakteristiki-konstruirovaniya-institutsionalnogodiskursa-v-kross-kulturnom-prostranstve

14. Hall Edward T. Beyond Culture. New York, London, Toronto : Anchor Books; Doubleday, 1976. 320 p.

15. Evans V., Successful Writing Proficiency. Blackpill, Swansea : Express Publishing, 2000. 160 p.

16. Hamp-Lyons L., Hyland K. EAP: issues and directions. Journal of English for Academic Purposes, 2002. Vol. 1 (1) 1-12. URL: https://www.researchgate.net/publication/222393560 EAP Issues and directions.

17. Hamp-Lyons L. Study Writing: A course in writing skills for academic purposes (second edition). Cambridge: Cambridge University Press, 2010. 214 p.

\section{REFERENCES}

1. Vasilieva, E. V. (2005). Navchannia studentiv movnykh spetsialnostei napysannia naukovoho problemno-tematychnoho povidomlennia anhliiskoiu movoiu [Teaching linguistic students to write scientific problem-thematic reports]. Extended abstract of candidate's thesis. Kyiv. nats. linhv. un-t. 2005. 24 p. [in Ukrainian].

2. Zahalnoievropeiski rekomendatsii z movnoi osvity: vyvchennia, vykladannia, otsiniuvannia [General European recommendations on linguistic education: studying, teaching, evaluating] (2003). Kyiv: Lenvit. 2003.273 p. [in Ukrainian].

3. Kaplich, L. V. (1996). Nekotoryie aspekty formirovaniya pismennoy rechevoi kompetentsii v linhvisticheskom vuze [Some aspects of formation of written speech competence in linguistic educational establishment]. Integratsiya lingvisticheskogo i ekstralingvisticheskogo znaniya. № 434. pp. 121-126. [in Russian].

4. Kurylo, S. V. (2013). Vpravy dlia navchannia maibutnikh vykladachiv anhliiskoi movy profesiino-oriientovanoho naukovoho pysemnoho movlennia [Exercises for teaching prospective English language teachers with professionally-oriented scientific written speech]. Inozemni movy. № 1. pp. 28-33. [in Ukrainian].

5. Pasov, E. I. (1991). Kommunikativnyie metodyi obucheniya inoyazyichnomu govoreniyu [Communicative methods to teach foreign language speech]. Moskva: Prosveschenie. 223 p. [in Russian]. 
6. Semenoh, O. \& Fast, O. (2015). Akademichne pysmo: linhvokulturolohichnyi pidkhid: navch. posib [Academic writing: linguistic cultural approach: textbook]. Sumy: SumDPU imeni A. S. Makarenka. 221 p. [in Ukrainian].

7. Synekop, O. S. (2010). Metodyka interaktyvnoho navchannia anhliiskoho pysemnoho movlennia maibutnikh fakhivtsiv z informatsiinoi bezpeky z vykorystanniam kompiuternykh tekhnolohii [Methodology of interactive teaching of English writing with computer technology for future computer security specialists]. Extended abstract of candidate's thesis. Kyiv. 310 p. [in Ukrainian].

8. Smirnova, N. V. (2015). Akademicheskaya gramotnost i pismo v vuze: ot teorii k praktike [Academic literacy and writing in higher educational establishment: from theory to practice]. Vysshee obrazovanie v Rossii. № 6. P. 58-63. [in Russian].

9. Tarnopolskyi, O. B., \& Kozhushko, S. P. (2008). Metodyka navchannia studentiv pysma anhliiskoiu movoiu [Methodology of teaching writing for students in English]. Vinnytsia: Nova knyha. 288 p. [in Ukrainian].

10. Tarnopolskyi, O. B. (2006). Writing Academically: A Coursebook for Teaching Academic Writing in English to Students of Linguistic Educational Institutions: Kyiv: INKOS. 228 p. [in Ukrainian].

11. Fentsyk, O. M. (2020). Formuvannia akademichnoi hramotnosti zdobuvachiv vyshchoi osvity u protsesi fakhovoi pidhotovky [Formation of students' academic literacy in the professional training process]. Pedahohika formuvannia tvorchoi osobystosti u vyshchii i zahalnoosvitnii shkolakh. Vol. 73. Nr. 2. Retrieved from: http://www.pedagogy-journal.kpu.zp.ua/ archive/2020/73/part_2/45.pdf [in Ukrainian].

12. Yakhontova, T. V. (2002). Osnovy anhlomovnoho naukovoho pysma: navch. posibnyk dlia studentiv, aspirantiv i naukovtsiv [Basics of English-speaking scientific writing: textbook for students, post-graduates, scholars] Lviv: Vydavnychyi tsentr LNU im. Ivana Franka. 220 p. [in Ukrainian].

13. Hutyz, I. P. (2017). Tipologicheskie harakteristiki konstruirovaniia instiutsionalnogo diskursa v kross-kulturnom prostranstve. [Typological features of discourse institutional organization in cross-culture space]. Filologicheskie nauki. Voprosyi teorii i praktiki. Tambov: Gramota. Vol. 10. № 1. Retrieved from: https://cyberleninka.ru/article/n/tipologicheskieharakteristiki-konstruirovaniya-institutsionalnogo-diskursa-v-kross-kulturnom-prostranstve. [in Russian].

14. Hall, Edward T. (1976). Beyond Culture. New York, London, Toronto: Anchor Books; Doubleday. 320 p.

15. Evans V. (2000). Successful Writing Proficiency. Blackpill, Swansea: Express Publishing. 160 p.

16. Hamp-Lyons L., Hyland K. (2002). EAP: issues and directions. Journal of English for Academic Purposes. Vol. 1 (1). P. 1-12. Retrieved from: https://www. researchgate.net/publication/222393560_EAP_Issues_and_directions

17. Hamp-Lyons L. (2010). Study Writing: A course in writing skills for academic purposes. Cambridge: Cambridge University Press. 214 p. 